\title{
COMMENTS
}

\section{PRIMARY JURISDICTION AND THE APPLICABIITY OF ANTITRUST REMEDIES IN THE SHIPPING INDUSTRY}

It has generally been assumed that the independent liner in competition with a conference of water carriers ${ }^{1}$ has no recourse to the antitrust laws for protection from conference efforts to limit his competition. ${ }^{2}$ His relief, if any, has appeared to depend on the Federal Maritime Board and its interpretation of the Shipping Act of 1916, ${ }^{3}$ which act is said to have superseded the antitrust remedies. Recent decisions, ${ }^{4}$ however, have cast doubt upon this view. Federal Maritime Board v. Isbrandtsen $\mathrm{Co}^{5}$ has called the problem into focus by holding that the Maritime Board may not approve conference agreements filed with it where the purpose of the agreement is to eliminate a competitor from the trade.

The Shipping Act of 1916 authorizes the Federal Maritime Board to exempt certain practices of ocean carries in foreign commerce from the operation of the federal antitrust laws. ${ }^{6}$ This exemption becomes operative, under the language of the Act, when the practice in question receives the approval of the Board. Section 15 of the Act provides that operation under an agreement not filed

1 A conference is a loose association of steamship lines operating under different flags regularly scheduled vessels over a particular trade route. Each member owns and occasionally operates his own vessels, and there is pooling of profits. One line may be a member of many conferences. Most conferences employ an arrangement designed to bind their shippers to ship exclusively by vessels operated by members of the conferences. These arrangements are sometimes referred to as "dual-rate systems," "contract/non-contract rate systems," or "exclusive patronage systems." Conference members actually or potentially compete for freight with tramp vessels, independent non-conference lines, industrial carriers, government operated ships, and vessels in the United States reserve fleet.

2 United States Navigation Co. v. Cunard S.S. Co., 284 U.S. 474 (1932); Terminal Warehouse Co. v. Pennsylvania R. Co., 297 U.S. 500 (1936); American Union Transp., Inc. v. River plate \& Brazil Conferences, 126 F.Supp. 91 (S.D.N.Y., 1954), aff'd 222 F.2d 369 (C.A.2d, 1955); Wisconsin \& Michigan Transp. Co. v. Pere Marquette L.S., 67 F.2d 937 (C.A.7th, 1933); Rivoli Trucking Corp. v. American Export Lines, 167 F.Supp. 937 (E.D.N.Y., 1958); Rivoli Trucking Corp. v. New York Shipping Ass'n, 167 F.Supp. 940 (S.D.N.Y., 1956), supplemental opinion rendered 167 F.Supp. 943 (S.D.N.Y., 1957); Isbrandtsen Co. v. United States, 81 F.Supp. 544 (S.D.N.Y., 1948), aff'd per curiam sub nom. A/S J. Ludwig Mowinckels Rederi v. Isbrandtsen Co., 336 U.S. 941 (1949).

339 Stat. 733 (1916), as amended, 46 U.S.C.A. $\$ 814$ et seq. (1958).

4 Federal Maritime Board v. Isbrandtsen Co., 356 U.S. 481 (1958) (shipping); United States v. R.C.A., 358 U.S. 334 (1959) (communications); Atchison, T. \& S.F.R. Co. v. Aircoach Transport Ass'n, 253 F.2d 877 (App.D.C., 1958) (railroads); Atlantic Coast Line R. Co. v. Riss \& Co., CCH Trade Reg. Rep. $\$ 69,122$ (App.D.C., 1958) (railroads).

s 356 U.S. 481 (1958).

639 Stat. 733 (1916), as amended, 46 U.S.C.A. $\$ 814$ (1958). 
for approval is violative of the Act. Where such a non-filed agreement has been judicially attacked as being violative of the antitrust laws, the Supreme Court has held that the district court had no jurisdiction to entertain the action. ${ }^{7}$ The plaintiffs must seek their remedy from the Maritime Board.

The notion of an exclusive primary jurisdiction in the Maritime Board stems from the Supreme Court decision in United States Navigation Co. v. Cunard S.S.Co. ${ }^{8}$ That case involved a suit by a steamship line which was the only competitor of a conference of carriers carrying ninety-five percent of the cargo trade from North Atlantic ports to Great Britain and Ireland. The complaint contained allegations of a combination by the member carriers designed to eliminate the plaintiff from competition. The conference, it was alleged, operated pursuant to dual-rate contracts with shippers who were penalized by a tariff as much as one-hundred percent higher for shipping on non-conference vessels. ${ }^{9}$ The plaintiff sought an injunction against the use of the rate system and against the combination as a violation of the antitrust laws. The agreement among the conference members had not been filed for approval with the Maritime Board. It was urged by the independent line that although section 15 of the Shipping Act exempted a conference agreement or modification of an agreement from the antitrust laws, failure to file the agreement or modification gained no exemption for the conference and left the antitrust remedy open.

The Court, however, refused to accept the approval provision as the demarcation between the operation of the two acts. The charges, the Court noted, were interrelated with possible violations of the Shipping Act. That Act had superseded the antitrust laws with respect to water carriers. The independent was therefore referred to the Maritime Board for his relief, and the complaint was dismissed. The Court reasoned by analogy to the doctrine of primary jurisdiction as applied to cases involving land carriers before the Interstate Commerce Commission. Since primary jurisdiction had been judicially developed ${ }^{10}$ with reference to the ICC, notwithstanding the provision in section 22 of the Interstate Commerce Act that the remedies of the Act were in addition to existing common-law and statutory remedies, a fortiori the doctrine should apply to water carriers as the Shipping Act contained no such express reservation of remedies.

7 United States Navigation Co. v. Cunard S.S. Co., 284 U.S. 474 (1932); Terminal Warehouse Co. v. Pennsylvania R. Co., 297 U.S. 500 (1936); Far East Conference v. United States, 342 U.S. 570 (1952).

8284 U.S. 474 (1932).

- The conference allegedly also employed other means to drive competitors from the trade. These included: "giving rebates; spreading false rumors and falsely stating that petitioner is about to discontinue its service; making use of their combined economic bargaining power to coerce various shippers, who are also producers of commodities used in large quantities by respondents, to enter into joint exclusive contracts with them; and threatening to blacklist forwarders and refuse to pay them joint brokerage fees unless they discontinue making, or advising shippers to make, shipments in petitioner's ships." Id., at 480.

${ }^{10}$ Texas and Pacific Ry. v. Abilene Cotton Oil Co., 204 U.S. 426 (190\%). 
At its next opportunity, the Court in Terminal Warehouse Co. v. Pennsylvania $R$. Co. ${ }^{11}$ amplified its Cunard decision. In a treble damage suit by a shipper against a railroad the Court relied on its interpretation of the Shipping Act in Cunard to deny damages under the Commerce Act. This time a further analogy between the Shipping and Commerce Acts was developed. Section 16 of the Clayton Act ${ }^{12}$ bars injunctive relief to private parties against carriers subject to the jurisdiction of the ICC ${ }_{r}$ Congress, the Court declared, most likely intended that the policy of the Commerce Act be carried over to the Shipping Act. Hence, injunctions would not be permitted against water carriers. While damage actions were not expressly barred by Section 16 of the Clayton Act, it was said that allowing such an action would permit complainant to "pass over" the regulatory act and revert to the antitrust laws for the recovery of damages. Therefore, the treble damage remedy had also been superseded.

Twenty years after Cunard, the Court in Far East Conference v. United States $^{13}$ again dismissed on the same grounds an antitrust suit by the government brought against a conference for operating under unfiled dual-rate agreements.

Lower courts have generally understood Cunard, Terminal and Far East as making the antitrust remedies unavailable against water carriers, ${ }^{14}$ for this has been the practical effect of dismissal of an antitrust complainant by a court when it defers to the Maritime Board.

It is true that in dismissing, the courts ostensibly employ the doctrine of primary jurisdiction..$^{15}$ That doctrine has been said to apply when "problems

11297 U.S. 500 (1936).

1238 Stat. 737 (1914), 15 U\}S.C.A. \$26 (1952).

13342 U.S. 570 (1952).

14 American Union Transp., Inc. v. River Plate \& Brazili Conferences, 126 F.Supp. 91 (S.D.N.Y., 1954), aff'd on opinion of the district judge, 222 F.2d 369 (C.A.2d, 1955); Wisconsin \& Michigan Transp. Co. v. Pere Marquette L.S., 67 F.2d 937 (C.A.7th, 1933); Rivoli Trucking Corp. v. New York Shipping Ass'n., 167 F.Supp. 940 (S.D.N.Y., 1956), supplemental opinion rendered 167 F.Supp. 943 (S.D.N.Y., 1957); United States v. Pacific Lumber Co,. CCH Trade Reg. Rep., T68,474 (N.D.Cal., 1956); United States Trucking Corp. v. American Export Lines, 146 F.Supp. 924 (S.D.N.Y., 1956); United States v. Borax Consolidated, Ltd., 141 F.Supp. 396 (N.D.Cal., 1955); United States v. Alaska Steamship Co., 110 F.Supp. 104 (W.D.Wash., 1952); New York \& Porto Rico S.S. Co. v. United States, 36 F.Supp. 190 (E.D.N.Y., 1940), reversing on rehearing 32 F.Supp. 538 (E.D.N.Y., 1940), disapproved, but appeal dismissed 116 F.2d 799 (C.A.2d, 1940); Swayne \& Hoyt v. Kerr Gifford \& Co., 14 F. Supp. 805 (E.D.La., 1935); New York Lumber Trade Ass'n v. Lacey, 245 App. Div. 262, 281 N.Y.S. 647 (1935), aff'd per curiam 269 N.Y. 595, 199 N.E. 688 (1935), modified on other grounds 269 N.Y. 677, 200 N.E. 54 (1936), cert. denied 298 U.S. 684 (1936).

${ }_{15}$ The decisions in Cunard and Terminal appeared to rest on jurisdictional grounds. But in Far East the Court discussed and rejected the advisability of a stay rather than dismissal. In United States v. Pacific Lumber Co., CCH Trade Reg. Rep., I68,474 (N.D.Cal., 1956), the Maritime Board intervened and moved to stay proceedings until it considered the matters stated in the action. But the court dismissed on jurisdictional grounds on the authority of Cunard and Far East. Although some antitrust proceedings have been stayed pending the resolution of administrative questions, courts hearing antitrust shipping cases have uniformly dismissed. 
which involve expert knowledge of multitudinous detail of intricate nature in a technical field require that recourse should be had to administrative bodies. Especially is this true where uniformity of interpretation of rules and consistency in application, in view of an overall policy, is compelled by the legislative mandate." 16 It is also sometimes said that in antitrust cases primary jurisdiction allows for a harmonization in the application of two statutes with variant objectives by two tribunals. ${ }^{17}$ But under the usual application of the doctrine the agency makes a preliminary determination which may or may not be dispositive of the issues. Supposedly, the plaintiff, if successful before the agency may resume his original action before the court. In S.S.W., Inc. v. Air Transport Ass'n of America, ${ }^{18}$ the Court of Appeals explained the procedure as consisting of a two-step process: after referral to the agency the plaintiff must show that the defendant violated the regulatory act; only then may he show in court that the defendant also violated the Sherman Act. If the court finally awards damages it is only for the violation of the antitrust law and not for the violation of the regulatory act. ${ }^{19}$

But as applied in Cunard and Terminal, it appears that if the plaintiff were successful before the Board in showing a violation of the regulatory act his relief lay in the provisions of that act. No return to the district court was contemplated. Where the remedy sought was an injunction as in Cunard, success before the Board would result in an order to cease and desist from the unlawful activity. If damages were claimed, as in Terminal and in other shipping cases, plaintiff must look to the reparation provision of the regulatory act for relief.

Several courts have regarded Cunard and Terminal as saying that upon referral to the Board under primary jurisdiction of a complaint seeking treble damages, the plaintiff must exhaust his reparations remedy ${ }^{20}$ which is deemed

${ }^{16}$ Trans-Pacific Airlines v. Hawaiian Airlines, 174 F.2d 63, 66 (C.A.9th, 1949). "[I]n cases raising issues of fact not within the conventional experience of judges or cases requiring the exercise of administrative discretion, agencies created by Congress for regulating the subject matter should not be passed over." Far East Conference v. United States, 342 U.S. 570, 574 (1952). "If a sufferer from the discriminatory acts of carriers by rail or by water may sue for an injunction under the Clayton Act without resort in the first instance to the regulatory commission, the unity of the system of regulation breaks down beyond repair." Terminal Warehouse Co. v. Pennsylvania R. Co., 297 U.S. 500, 513 (1936). See Keogh v. Chicago \& N.W. Ry., 260 U.S. 156, 163 (1922).

17 "That some resolution is necessary when the antitrust policy of free competition is placed beside a regulatory scheme involving fixed rates is obvious." United States v. R.C.A., 358 U.S. 334, 348 (1959). See Pennsylvania Water \& Power Co. v. Federal Power Comm'n, 193 F.2d 230, 234 (App.D.C., 1951); Apgar Travel Agency, Inc. v. International Air Transport Ass'n, 107 F.Supp. 706 (S.D.N.Y., 1952); The Supreme Court, 1951 Term, 66 Harv. L. Rev. 89, 158 (1952).

${ }^{18} 191$ F.2d 658 (App.D.C., 1951), cert. denied 343 U.S. 955 (1953). $\quad{ }^{19}$ Id., at 664.

${ }^{20}$ See S.S.W., Inc. v. Air Transport Ass'n of America, 191 F.2d 658, 663 (App.D.C., 1951), cert. denied 343 U.S. 955 (1953); Trans-Pacific Airlines v. Hawaiian Airlines, 174 F.2d 63, 66 (C.A.9th, 1949); Apgar Travel Agency, Inc. v. International Air Transport Ass'n, 107 F.Supp 706, 711 n.15 (S.D.N.Y., 1952). This is apparently the basis for the decisions in two damage 
an adequate substitute for antitrust damages. But it is a further step to the belief which seems to be implicit in the invocation of the doctrine by other courts, ${ }^{21}$ that the whole shipping industry is exempt from the antitrust laws. ${ }^{22}$

It is in the context of the relationship between the Shipping Act and the antitrust laws that the decision in Federal Maritime Board v. Isbrandtsen Co., reinterpreting Cunard and Far East, appears to have significance, particularly with respect to the future availability of the Sherman Act against the conferences. On appeal from a Board decision approving a dual-rate system similar to the one present in Cunard and Far East, the Supreme Court affirmed a reversal of an approval by the Board. The Court held that the Maritime Board cannot approve conference agreements having the purpose and effect of stifling the competition of independent carriers. The dual-rate system was unlawful as a "resort to other discriminating or unfair methods" under section 14 Third of the Shipping Act..$^{23}$ The Board had argued that such a decision was foreclosed by Cunard and Far East. Had the Court then thought that the agreements embodying the dual-rate system were unlawful under the Act it would not have referred the matter to the Board. The Court would originally have declared them illegal. To this contention the Court replied:

[T] he Court's action in Cunard and Far East Conference is to be taken as a deferral of what might come to be the ultimate question ... rather than an implicit holding that the Board could properly approve the practices there involved. ${ }^{24}$

Isbrandtsen seems to represent a retreat from primary jurisdiction as applied in Cunard. Whereas in Cunard, Terminal and Far East the Court appeared to relinquish to the agency complete authority to dispose of the issues, Isbrandtsen appears to take a lesser view of the Shipping Board's authority. Primary jurisdiction is explained as "a device to prepare the way, if the litigation should take its ultimate course, for a more informed and precise determination by the Court of the scope and meaning of the statute as applied to those particular circumstances." ${ }^{25} \mathrm{It}$ is for the Board to determine initially the predatory nature of an

actions dismissed against conferences. American Union Transp., Inc. v. River Plate \& Brazil Conferences, 126 F.Supp. 91 (S.D.N.Y., 1954), aff'd 222 F.2d 369 (C.A.2d, 1955); Rivoli Trucking Corp. v. New York Shipping Ass'n, 167 F.Supp. 940 (S.D.N.Y., 1956), supplemental opinion rendered 167 F.Supp. 943 (S.D.N.Y., 1957).

${ }^{21}$ Rivoli Trucking Corp. v. American Export Lines, 167 F.Supp. 937 (E.D.N.Y., 1958); Rivoli Trucking Corp. v. New York Shipping Ass'n, 167 F.Supp. 940 (S.D.N.Y., 1956), supplemental opinion rendered 167 F.Supp. 943 (S D.N.Y., 1957); United States v. Pacific Lumber Co., CCH Trade Reg. Rep., T68,474 (N.D.Cal., 1956); United States v. Borax Consolidated, Ltd., 141 F.Supp. 396 (N.D.Cal., 1955); United States v. Alaska Steamship Co., 110 F.Supp. 104 (W.D.Wash., 1952); American Union Transp., Inc. v. River Plate \& Brazil Conferences, 126 F.Supp. 91 (S.D.N.Y., 1954), aff'd 222 F.2d 369 (C.A.2d., 1955).

${ }_{22}^{2}$ The importance of the step is of course accentuated where unfiled agreements contain matter which possibly could not be approved by the Maritime Board.

2839 Stat. 733 (1916), as amended, 46 U.S.C.A. $\$ 812$ (1952).

24356 U.S. 481,498 (1958).

${ }^{25}$ Id., at 498-99. 
agreement. But Isbrandtsen emphasizes that referral is made to utilize the Board's fact-finding capacity as an aid to the court, and not for the independent disposition of the issues.

Justice Frankfurter, dissenting in Isbrandtsen, attacked the majority holding as making a "circumlocution office" out of the Board. ${ }^{26}$ Indeed, the Court had previously said that the Board had expertise; that uniformity of regulatory supervision must be preserved; and that the resolution of the divergent policies of antitrust and the Shipping Act is accomplished by the supersession of the former. It is now somewhat surprising, declared Mr. Justice Frankfurter, to be told that the Board may not approve an agreement which it has thoroughly investigated and which it believes to be in the interests of the maritime policy of the United States. ${ }^{27} \mathrm{It}$ is more so, as the decision overturns forty years of industry practice on grounds closely resembling antitrust. ${ }^{28}$

Contrary to the broad language of supersession in Cunard and Terminal, the majority in Isbrandtsen appears unwilling to defer to the Maritime Board an issue so closely related to antitrust. On the other hand, Mr. Justice Frankfurter views the antitrust exemption provision as indicative of the broad powers of the Board. There is no doubt in his opinion that the Shipping Act left little of the antitrust laws applicable to shipping. ${ }^{29}$ Of course Isbrandtsen does not directiy answer the question of the extent of antitrust applicability to shipping conferences. That question was not directly before the Court..$^{30}$ But in freeing independent carriers from Board-approved predatory agreements, the decision in several ways indicates that antitrust may apply.

${ }^{26} \mathrm{Id}$., at 518.

${ }^{27}$ Mr. Justice Frankfurter may have had the statement of Mr. Justice Harlan in United States v. Western Pacific R. Co., 352 U.S. 59, 65 (1956), particularly in mind. The doctrine of primary jurisdiction " 'transfers from court to agency the power to determine' some of the incidents of such relations." (Emphasis added.)

But the fact that a court permits the expert to make his finding first does not appear to mean that the court is bound by it. The opinion in Cunard contained references to the "preliminary" jurisdiction of the Board and the injudiciousness of taking jurisdiction "in advance." In Far East it was a "preliminary" resort; and even elsewhere in Western Pacific (not an antitrust case) the Court spoke of "initial" consideration. See also, New York Susquehanna \& Western R. Co. v. Follmer, 254 F.2d 510 (C.A.3d, 1958), where the court compared a postreferral administrative report with the report of a master.

${ }^{28}$ The dual rate appears to have been widely adopted shortly after the passage of the Shipping Act in 1916. Hearings Before the House Committee on Merchant Marine and Fisheries on H.R. 12751, 85th Cong. 2d Sess. 31 (1958).

Prior to the Act the practice of conferences was to tie shippers to conference vessels by means of a deferred rebate system. The shipper was to receive a percentage rebate of the tariff periodically. The conference delayed payment of rebates for several periods. A shipper choosing to transport by non-conference vessels lost all that was due him. Frequently, the shipper's rebate also depended on the loyalty of consignees to whom the shipper may have sold goods during the period of probation. See Thomsen v. Cayser, 243 U.S. 66 (1917). Section 14 of the Shipping Act expressly outlawed deferred rebates. 39 Stat. 733 (1916), as amended, 46 U.S.C.A. $\$ 812$ (1958).

${ }^{29} 356$ U.S. $481,512-13$ (1958).

${ }^{30}$ The contention that it was, was rejected in Riss \& Co. v. Association of American Railroads, 170 F.Supp. 354 (D.D.C., 1959). 


\section{I}

The exemption provision in the Shipping Act indicates that the full range of antitrust shall not apply. But that provision does not eliminate the possibility that antitrust was intended to apply to situations of non-approval, disapproval and to situations relating to certain types of approval.

The question of the applicability of the antitrust laws arises when the defense of primary jurisdiction is presented to an antitrust suit. In its most recent statement on the doctrine of primary jurisdiction ${ }^{31}$ the Supreme Court considered the answers to three questions of particular importance: (1) Did Congress in enacting the regulatory statute intend to limit the applicability of the antitrust laws; (2) Is there an all-pervasive scheme of regulation; (3) Is there a question of rate-making or rate regulation involved?

The 1913 Report of the Committee on Merchant Marine and Fisheries ${ }^{32}$ is the first legislatively significant event in the history of the Shipping Act. The Committee concluded that the antitrust laws had failed to prevent the formation of shipping conferences, and that existing legislation was unsuited to correct conference abuses. ${ }^{33}$ The Report stated that the conferences preferred a system of regulation rather than the elimination of the conference system. ${ }^{34}$ Although the system permitted abuses, the Committee concluded that conferences did benefit the industry generally and should be legalized. ${ }^{35}$ Accordingly, in several preliminary attempts to enact a regulatory statute, the Committee presented proposals to Congress to place the conferences under governmental regulation. But apparently each of these proposals differed..$^{36}$ The bill that finally did pass, appended to another, more controversial measure, ${ }^{37}$ was rushed through under a rule limiting discussion, ${ }^{38}$ and contained no statement relating to antitrust further than a recitation of section 15 that approval of an agreement by the Board would result in exemption. ${ }^{39}$

31 United States v. R.C.A., 358 U.S. 334 (1959).

${ }^{32}$ H.R. Doc. No. 805, 63 Cong. 2d Sess. 416 (1914).

${ }^{33}$ RepresentativeAlexander, Chairman of the Committee, 53 Cong. Rec. 8,077, 8,095 (1916). There appears to have been strong sentiment in Congress in 1910-12 that shipping conferences were violative of the antitrust laws. See H.R. Rep.No. 502, 61st Cong. 2d Sess. 4 (1910); see also, H.R. Rep.No. 2058, 61st Cong. 3d Sess. (1911). H.R. 1010, 62d Cong. 2d Sess. (1912), provided severe penalties against conferences upon conviction of antitrust violation. The bill passed the House but was defeated by a Senate filibuster. 48 Cong. Rec. 7,561 (1912).

3453 Cong. Rec. 8,078 (1916).

${ }^{35} \mathrm{Id}$., at 8,077 . $\quad{ }^{36} \mathrm{Id}$., at 8,071 .

${ }^{37}$ See Frankfurter, J., dissenting, in Federal Maritime Board v. Isbrandtsen Co., 356 U.S. 481, 510 (1958); Current Legislation, 17 Col. L. Rev. 354, 357-58 (1917); 53 Cong. Rec. 8,089 (1916).

${ }^{38}$ Id., at 8,070-75.

${ }^{39}$ The provisions of the Federal ship-buying program were repealed and the plan abandoned in the 1920 Merchant Marine Act, 41 Stat. 988 (1920), as amended, 46 U.S.C.A. $\$ 861$ et seq. (1958). 
However, it is clear that at the time of the Act Congress was concerned with the diversion of privately owned vessels to the European trade made profitable by the war. ${ }^{40}$ The rapid increase in rates and the likelihood of an American participation in the war created a sharp demand for an immediate increase in domestic merchant tonnage. The coupling of the regulatory provisions with the government ship-purchase program indicates how Congress hoped to achieve this increase. First, federal money was to buy or lease ships. Second, private capital was to be encouraged into shipbuilding and shipowning. ${ }^{41}$ But the latter goal could not be accomplished unless shipowners believed that they would be able to operate at a profit not only during the war but after it as well. Since the industry had been overtonnaged before the war-accelerated demand, it was natural to suppose that after the crisis rates would fall. Therefore, it would appear that the purpose of the conferences was at least in part to prevent such a result. ${ }^{42}$ The conferences were to be permitted to set their own rates, subject to approval by the Maritime Board. ${ }^{43}$

Permitting carriers in concert to set the legal tariff was an attempt to guarantee profitable operations to shipowners. ${ }^{44}$ But if conferences were thus to be encouraged, Congress must have realized that it would be at the expense of independent carriers. One view of the conference system is that if independent carriers may operate along the same routes at lower rates, the conference rate cannot be effectively maintained..$^{45}$ Under this view the exemption provision in the Shipping Act indicates that Congress thought it could best encourage

1053 Cong. Rec. 8,079 (1916).

11 Provisions were made in the bill to ensure that government ships would not compete directly with privately owned vessels. 53 Cong. Rec. 8,079 (1916).

12 Congress had previously considered providing direct subsidies to private shipowners. The idea was rejected, apparently for the reason that it would be incongruous to grant public funds to operating shipowners who at the time were enjoying exorbitant profits. 53 Cong. Rec. 8,086 (1916). But in 1936 Congress did finally begin subsidizing the industry. 49 Stat. 1995 (1936), as amended, 46 U.S.C.A. $\$ 1151$ et seq. (1958).

${ }^{43}$ The Board could not disapprove rates merely because it thought them unreasonably high. Isbrandtsen Co. v. United States, 96 F.Supp. 883, 893-94 (S.D.N.Y., 1951), aff'd per curiam sub nom. A/S J. Iudwig Mowinckels Rederi v. Isbrandtsen Co., 342 U.S. 950 (1952), where Judge Frank makes this clear. The Board may disapprove of "unjustly discriminatory" rates or rates that operate "to the detriment of the commerce of the United States." 39 Stat. 733 (1916), as amended, 46 U.S.C.A. $\$ 814$ (1958). The Board has not sought to control high rates through interpretive extension of its ambiguous statutory mandate. See Edwards, Maintaining Competition 5 (1949).

4" "[W]e have no merchant marine and all our products shipped by sea are carried by German, English, and French bottoms. I want to see the American flag float over our shipping as it did, 50,60,70 years ago. It will never come by private enterprise, because there is not enough profit in it to encourage private enterprise."Representative Miller, 53 Cong. Rec. 8,071 (1916).

${ }^{45}$ This is the unanimous contention of spokesmen for conference carriers. Numerous statements to this effect are to be found in the Report of the Committee on Merchant Marine and Fisheries, note 32 supra; Hearings Before the House Committee on Merchant Marine and Fisheries, on H.R. 12751, 85th Cong. 2d Sess. (1958). This is also substantially the view of the Maritime Board. Id., at 241-50. 
shipping by encouraging conference members to expand. But a small conference if given unlimited legal protection could thwart the entrance of any vessel into a profitable trade, and in this manner destroy the objective of increasing investment in shipping by independent shipowners. The solution, a compromise apparently favoring the conferences, was a provision in the Shipping Act requiring the admission of a qualified independent upon proper application. ${ }^{46}$

In light of the admission provision, it is questionable whether the policy of the antitrust laws can be said to apply, even where there has been no compliance with the requirements of exemption. Conference agreements may be said to be as much designed to force the independent to join the combination as to eliminate him from the trade. ${ }^{47}$ Hence, there could be no predatory conference agreements aimed at independents.

It would appear that Congress attained both its goals in the compulsory admission provision: the greatest number of ships were encouraged, and the conference system was preserved. This implies that Isbrandtsen was erroneously decided; that the Shipping Act was intended to condone conference agreements aimed at independents; and that in the absence of express Board approval, resort should not be had to the antitrust laws to defeat congressional objectives.

This analysis of congressional intent, however, seems to conflict with the conclusion suggested by the knowledge that Congress intended the Maritime Board to operate in the same manner as the ICC.48 The exemption clause of the Shipping Act did not exist in the Commerce Act; moreover, the Commerce Act did have a clause expressly reserving common-law and other statutory remedies which was lacking in the Shipping Act. Perhaps the answer is that the Shipping Act was designed to conform to the Commerce Act as interpreted by the courts rather than as written. ${ }^{49}$ The exemption provision, for example, was probably a legislative means of incorporating the rule of reason adopted by the Supreme Court in the Standard Oil case. ${ }^{50}$ The drafters of the Shipping Act no doubt

1641 Stat. 996 (1920), as amended, 46 U.S.C.A. $\$ 813$ (1958).

${ }^{47} \mathrm{It}$ is of course necessary to keep in mind the broad scope of conference agreements. These frequently regulate all phases of a member's activity. Were such agreements merely rate arrangements as was urged both by Cunard and by the government in the Far East case, one could perhaps distinguish between price fixing agreements and predatory tactics. But section 15 of the Shipping Act apparently makes lawful all the provisions of such agreements subject to approval by the Board. See note 43 supra.

4853 Cong. Rec. 8,081-82, 8,095-96 (1916).

49 E.g., "The provisions of section 27 relating to the power of the board to compel the attendance of witnesses and the production of documentary and other evidence are also substantially similar to those of the interstate-commerce act, except that the board may exercise such power only 'for the purposes of investigating alleged violations of this act' instead of 'for the purposes of this act' as in the interstate-commerce act. Under this broad phrase in the latter act as construed by the Supreme Court (Harriman v. United States, 211 U.S. 407 [1908]), the power of the board is limited to investigations of violations." Representative Alexander, Chairman of the Committee on Merchant Marine and Fisheries that drafted the bill. 53 Cong. Rec. 8,081 (1916).

${ }^{50}$ Standard Oil Co. of New Jersey v. United States, 221 U.S. 1 (1911). 
wished to leave to an administrative agency, rather than to the courts, the job of sifting through the data which would indicate the reasonableness of any agreement..$^{51}$ But it may be doubted whether they intended to grant exemption to an agreement which then would plainly not have been regarded as reasonable by the courts. ${ }^{52}$ Thus, ten years after the Shipping Act was enacted, in a suit against a conference involving technical matters of the shipping industry, ${ }^{53}$ where the challenged practice was patently unreasonable, no mention was made by the Supreme Court of any exemption that the Shipping Act could provide. ${ }^{54}$

After Cunard, however, courts began referring matters to the agency no matter how extreme the allegations. ${ }^{55}$ A notable exception was the case of Slick Airways, Inc. v. American Airlines, ${ }^{56}$ where a claim of possible exemption under an exemption provision in the Civil Aeronautics $\mathrm{Act}^{57}$ similar to the provision in the Shipping Act was made by the defendant airline in defense of a treble damage action. District Judge Forman emphatically rejected "the suggestion

${ }^{51}$ Standard Oil Co. of California v. United States, 337 U.S. 293, 310 n.13 (1949).

52 "There is no similar provision in the Interstate Commerce Act. Its inclusion in the present statute, therefore, seems to give legislative sanction to the recent tendency of the courts to permit reasonable restraints on free competition, in the interest of greater efficiency in the management of important industries." Current Legislation, 17 Col. L. Rev. 354, 358-59 (1917), cited, apparently for this observation, in United States v. American Union Transport, 327 U.S. 437,447 n.8, (1946).

Even in Standard Oil the Court, while rejecting the Trans-Missouri and Joint Traffic rejection of the rule of reason, also concluded that the type of arrangement in those cases-price fixing - was inherently unreasonable. 221 U.S. 1, 65 (1911). In Thomsen v. Cayser, 243 U.S. 66, 84-86 (1917), decided after the Shipping Act became law, the Court declared that conference activities had been inherently unreasonable before the Act. It was the opinion of the British Royal Commission on Shipping Rings reporting on the legality of conferences that such arrangements were illegal under the Sherman Act. The Law as to Combinations, $10 \mathrm{~J}$. Soc. of Comp. Leg. 144, 175 (1909). The same view was expressed in Attorney General v. Adelaide S.S. Co., [1913] A.C. 781.

${ }^{63}$ Anderson v. Shipowners' Ass'n, 272 U.S. 359 (1926). A unanimous court opinion in both this case and Cunard was written by Justice Sutherland.

"In Buyer v. Guillan, 271 Fed. 65 (C.A.2d, 1921), an injunction was granted against a conference without mention of the primary jurisdiction of the Maritime Board. In Burgess Bros. Co. v. Stewart, 114 Misc. 673, 187 N.Y.S. 873 (S.Ct., 1921), an injunction against a conference was granted for violation of the New York Criminal Code and for violation of sections of the Shipping Act. Here as well, no question of the primary jurisdiction of the Maritime Board was discussed. See also, Copper River Packing Co. v. Alaska S.S. Co., 22 F.2d 12 (C.A.9th, 1927); European Commercial Co. v. International Mercantile Marine Co., [1923] A.M.C. 211 (S.D.N.Y., 1923). Since courts may hold that referral to the Board is necessary without such claim being made by either party, these cases indicate that until Cunard no court construed the Shipping Act either as completely exempting shipping from the antitrust laws, or as necessitating primary jurisdiction. Compare the use made by the Supreme Court of the doctrine of contemporaneous construction in United States Alkali Ass'n v. United States, 325 U.S. 196, 208 (1945).

B5 See cases cited notes 2, 14, 22 supra.

${ }^{56} 107$ F. Supp. 199 (D.N.J., 1952), appeal dismissed sub nom. American Airlines, Inc. v. Forman, 204 F.2d 230 (C.A.3d, 1953), cert. denied 346 U.S. 806 (1953).

5752 Stat. 1004 (1938), 49 U.S.C.A. $\$ 494$ (1952). 
that a conspiracy to drive a competitor out of business ... is the type of agreement encompassed within the statute and subject to the primary jurisdiction of the $\mathrm{CAB}$ for approval or disapproval and for possible immunity from the antitrust laws. ${ }^{358}$ It seemed plain to him that the exemption provision in a regulatory act applied only to those agreements "which are contracts openly arrived at rather than secret conspiracies." More specifically, Congress intended to permit the regulated firms to get together to fix rates and establish industrywide uniformity of standards and conditions. These activities Congress considered normal business functions desirable for the efficient organization of the industry. But were it not for the immunity provision, such activities would be technical violations of the antitrust laws. Judge Forman believed that immunity extends only to these open agreements in contradistinction to a "secretive and furtive" conspiracy to restrain trade. Unfiled predatory agreements are in the latter class.

The Forman view finds some support in the Act. The exclusion of tramps, ${ }^{59}$ which differ from other liners principally in the regularity of service they provide, ${ }^{60}$ indicates that the Act was concerned with immunizing such open and normal business agreements as those which dealt with the regularity of service. The Forman view is, however, a minority position. ${ }^{61}$ No doubt the hesitancy of other courts in adopting this view can be attributed to the fact that prior to the Isbrandtsen case there had been no explicit limitation set upon the authority of the Board to approve. ${ }^{62}$ Henceforth the Shipping Board may not approve agreements aimed at non-members. If such agreements cannot be approved, then by definition they are not within normal business needs. Conversely, agreements limiting competition between conference members may be approved. Since what may be classified as business needs concerns the activities of members to the agreement and would not normally consist of agreements

${ }^{58}$ Slick Airways, Inc. v. American Airlines, 107 F.Supp. 199, 207 (D.N.J., 1952).

${ }^{59} 40$ Stat. 900 (1918), as ammended, 46 U.S.C.A. $\$ 801$ (1952). See Brown \& Williamson Tobacco Corp. v. The S.S. Anghyra, 157 F.Supp. 737, 752 (E.D.Va., 1957).

${ }^{60}$ There are other varying characteristics. Tramp vessels generally carry bulk cargo. UsualIy, they carry less than three types of goods on any single trip. While tramps only compete for the general merchandise freight of liners in periods of cargo shortage, liners are always ready to carry bulk cargo at liner rates. See generally, Hearings Before the Subcommittee on Maritime Affairs of the Committee on Merchant Marine and Fisheries on H.R. 6719, 85th Cong. 2d Sess. (1950).

61 In varying degrees, other courts have approached this position. See Georgia v. Pennsylvania R. Co., 324 U.S. 439 (1945); Atchison, T. \& S.F. Ry. Co. v. Aircoach Transport Ass'n, 253 F.2d 877 (App.D.C., 1958); Pennsylvania Water \& Power Co. v. Consolidated Gas, E. L. \& P. Co., 184 F.2d 552 (C.A.4th, 1950), supplemental opinion rendered, 186 F.2d 934 (1951), cert. denied 340 U.S. 906 (1951); United States v. Association of American Railroads, 4 F.R.D. 510 (D.Neb., 1945).

62 "But with the broad power of exemption possessed by the Board under the Civil Aeronautics Act, we cannot know the extent of exemption until the Board has acted." Apgar Travel Agency, Inc. v. International Air Transport Ass'n, 107 F.Supp. 706, 710 (S.D.N.Y., 1952). 
specifically aimed at non-members, it would appear that the Court in Isbrandtsen is heading toward Judge Forman's view.

Although the Isbrandtsen premise that there can be such a thing as a conference agreement which has a function other than the elimination of outside competition invites some speculation, it appears that its validity can be demonstrated. Prior to Isbrandtsen, the most effective retaliatory measure employed by the conferences was the dual-rate system. Under this plan a shipper who utilized the facilities of the independent would be subjected to a higher rate on those goods which he sent by conference liners; of course he would have to use conference liners to some extent, and the savings realized by shipping with an independent were cancelled out by the increased conference rate. ${ }^{63}$ Thus, even the bulk shipper, for example, who did not need or want the speed, service or regularity of the conference liner and who did not want to pay for them, was forced to ship via conference vessels exclusively because of the operation of the dual-rate system. Isbrandtsen eliminates such predatory agreements, and allows only normal business agreements. To the argument of the conferences that such an interpretation will undercut conference rates and destroy the whole conference system it should be replied that for many shippers the liner service which only the conference can provide is indispensable; as to this service, the independents are no competition. Thus, the independents and tramps will only be enabled to compete for that trade which the conferences have heretofore provided with unnecessary and unwanted services.

II

Although it may not be inconsistent with regulatory policy for antitrust policy to apply to shipping conferences, it would appear that antitrust could only apply where there has been no valid Board approval. The defense of primary jurisdiction to an antitrust suit was said by the Court in United States $v$. R.C.A. ${ }^{64}$ to be applicable where the defendant belongs to an industry where there is an all-pervasive scheme of regulation. The plaintiff in Cunard appears to have argued on the theory that the exemption granted by the Shipping Act was only in return for a submission by the carriers to a system of regulation. The defendant conference had not filed the agreement among the members to institute a dual-rate system with the Shipping Board. The plaintiff further insisted that had the agreement been filed, the Board would not have approved it. ${ }^{65}$ Failure to submit to the scheme of regulation, it was argued, left an antitrust remedy open. These contentions were flatly rejected by the Court:

6s See Swayne \& Hoyt, L.td. v. United States, 300 U.S. 297, 306 (1937).

ธ4 358 U.S. 334 (1959).

${ }^{65}$ It seems more likely that the Board would have approved. A dual-rate agreement had been disapproved for an intercoastal conference in Eden Mining v. Bluefield Fruit \& Steamship Co., 1 U.S.S.B. 41 (1922). But a similar agreement was subsequently approved for a conference of carriers in foreign commerce. Rawleigh v. Stoomvaart, 1 U.S.S.B. 285 (1933). 
[W] hatever may be the form of the agreement, and whether it be lawful or unlawful upon its face, Congress undoubtedly intended that the board should possess the authority primarily to hear and adjudge the matter.

While competitors of shipping conferences have been largely unsuccessful in urging strict compliance with the exemption provision of the Shipping Act, strict compliance with the exemption provisions of other acts has been required by the Court in several cases. ${ }^{67}$ The rationale of these cases was successfully applied against conferences in two cases ${ }^{68}$ where the conference attempted to enforce a penalty clause in an unfiled dual-rate contract. The defense to both actions was that the contracts violated the Shipping Act and the antitrust laws. The conference urged that the courts refer the question of approval of the conference agreement to the Maritime Board. But the courts refused to permit retroactive immunization of the agreements.

Not only is there dicta to the effect that failure to file will leave the antitrust remedy open, ${ }^{69}$ but the district court so held in United States v. Far East Conference. ${ }^{70}$ As in Cunard, the conference had failed to file dual-rate agreements. The court reasoned that the exemption granted by section 15 of the Shipping Act might be interposed as a substantive defense but could not be raised as a procedural bar to the right of the United States to prosecute the antitrust action. Since no approval by the Board had been sought, the conference had no defense to the action. ${ }^{71}$ The district court distinguished Cunard as a private

${ }^{66}$ United States Navigation Co. v. Cunard S.S. Co., 284 U.S. 474, 487 (1932). "[A] failure to file such an agreement with the Board will not afford ground for an injunction under $\$ 16$ of the Clayton Act at the suit of private parties ... since the maintenance of such a suit, being predicated upon a violation of the antitrust laws, depends upon the right to seek a remedy under those laws, a right which, as we have seen, does not here exist." Id., at 486.

${ }^{67}$ United States v. Borden Co., 308 U.S. 188 (1939); United States Alkali Ass'n v. United States, 325 U.S. 196 (1945); American Cooperative Serum Ass'n v. Anchor Serum Co. 153 F.2d 907 (C.A.7th, 1946), cert. denied 329 U.S. 721 (1946).

${ }^{68}$ River Plate and Brazil Conferences v. Pressed Steel Car Co., 227 F.2d 60 (C.A.2d, 1955); Pacific Westbound Conference v. Leval \& Co., 201 Ore. 390, 269 P.2d 541 (1954), cert. denied 348 U.S. 897 (1954).

${ }^{69}$ United States v. American Union Transp., 327 U.S. 437, 447 n.8 (1945); Isbrandtsen Co. v. United States, 211 F.2d 51, 57 (App.D.C., 1954), cert. denied 347 U.S. 990 (1954); Atlantic and Gulf West Coast Conference v. United States, 94 F.Supp. 138, 141 (S.D.N.Y., 1950).

7094 F.Supp. 900 (D.N.J., 1951).

${ }^{71}$ The same rationale in an antitrust shipping case is only to be found in an early district court opinion written by Judge Augustus Hand. In European Commercial Co., v. International Mercantile Marine Co., [1923] A.M.C. 211 (S.D.N.Y., 1923), the unfiled agreement was to fix prices and to exclude steamship ticket agents not agreeable to the conference from selling tickets for the Mediterranean trade. The conference urged upon the court that the antitrust laws were inapplicable to it. "[T] he trade agreements most [sic] have been filed if it [sic] is to be relied on as bringing the case within the exception from the operation of the Sherman AntiTrust Act. ... It also must have been approved by the Shipping Board if made subsequent to the organization thereof. To bring the case within the exception would seem to be a matter of defense." Id., at 215. The plaintiff was allowed both injunctive relief and damages. (Strange- 
action and not a government suit. On appeal, ${ }^{72}$ however, the Supreme Court saw no reason for such a distinction. It chose to reaffirm Cunard. The government was referred to the Board. ${ }^{73}$

That failure to file as required by section 15 should thereby allow the antitrust suit was rejected by Cunard and Far East on the ground that the Board was authorized to afford relief for that violation. Section 31 specifies a fine of $\$ 5,000$ for violations of the Act except where other penalties are provided for violations of specific subsections. The remedy for a violation of section 15 appears at the end of that subsection:" "Whoever violates any provision of this section shall be liable to a penalty of $\$ 1,000$ for each day such violation continues, to be recovered by the United States in a civil action." Thus the failure to file would appear to be exclusively remediable before the court and not the Board. The government antitrust suit, as in Far East, has as its purpose the same end as this provision: that the conference either file the agreement and submit to regulation, or cease the activity. ${ }^{75}$ But if this is correct, then it would appear inconsistent to require the government to proceed to its objective under the Shipping Act before a court, and under the antitrust laws before the Board. ${ }^{76}$

ly, this opinion was not reported by any of the standard reporters of the day. Even in the first volume of the American Maritime Cases it is not to be found in theindex. Asfar as appears the case has never been cited, even by plaintiffs.)

72342 U.S. 570 (1952).

${ }^{73}$ The Far East holding was immediately extended to cover criminal suits brought by the government against conferences. United States v. Alaska Steamship Co., 110 F.Supp. 104 (W.D.Wash., 1952).

739 Stat. 733 (1916), as amended, 46 U.S.C.A. $\$ 814$ (1958).

75 "[W]hile, because of necessity in connection with the maintenance of adequate sea transportation for this country, Congress felt that the steamship companies could combine and operate to some extent in restraint of trade and carry on a monopolistic practice, for the protection of the public interest this was to be permitted only under due and proper supervision." Pacific Westbound Conference v. Leval \& Co., 201 Ore. 390, 393, 269 P.2d 541, 543 (1954), cert. denied 348 U.S. 897 (1954).

As long as the conference does not file a dual-rate system, the members may apply the system with arbitrary severity. The higher rate may have been filled prior to the agreement to initiate dual-rates. Or, the members may file the higher rate as a new rate to displace a former tariff, after the agreement. But no rate lower than the filed rate may legally be changed. Thus, shippers signing the conference dual-rate form enter into agreements which the conference may enforce for any suspected breach. But neither the Maritime Board nor any court will sustain the claim of a shipper for the lower contract rate. Black Diamond S.S. Corp. v. S. H. Kress \& Co., 284 N.Y.S. 310, 157 Misc. 360 (S.Ct., 1935).

${ }^{76}$ Which type of proceeding the government chooses to bring may be important to the independent. Under section $\mathbf{5}$ of the Clayton Act, a government antitrust decree serves as prima facie evidence in a subsequent private suit against the same defendant. But a government proceeding under any provision of the Shipping Act does not benefit future plaintiffs. Cf. Proper v. John Bene \& Sons, 295 Fed. 729 (E.D.N.Y., 1923). Section 5 is part of a legislative policy of minimizing the burden of litigation for injured private suitors and complementing the government in enforcing the antitrust laws. Emich Motors Corp. v. General Motors Corp., 340 U.S. 558 (1951).

There is also a practical difference in the deterrent effect of the antitrust and Shipping Act 
Although the Shipping Act makes non-filing of an agreement unlawful, and provides a penalty for its violation, the conferences are able safely to assume the risks of non-filing through the application, or frequently the misapplication, of the doctrine of primary jurisdiction. When the conference receives notice of a forthcoming antitrust suit, there is ample opportunity to seek the shelter of exemption by filing and having approved all agreements which tend to prove the conspiracy. But to file with the Board is to assume the risk of disapproval before the antitrust suit.

By not filing, two defenses remain open to the antitrust suit. First, the conference denies any combination to eliminate the independent. Second, and in spite of the first defense, the conference insists that if there is an agreement the proper forum is the Maritime Board, as the combination might be lawful and the Board should be allowed to exempt it from antitrust liability. When the court dismisses in deference to the Board, the conference still need not file the agreement as it may continue to maintain that there is no conspiracy, and hence nothing to file with the Board. The burden then remains with the plaintiff to initiate proceedings with the Board. Before the Board, the charge of conspiracy may be denied. Plaintiff will then be forced to prove all that he would have had to prove in the antitrust suit. If the plaintiff is successful before the Board in showing an unfiled agreement, the conference may still hope that the agreement will then be approved by the Board. If the agreement is approved, the conduct of the parties to the agreement is immunized retroactively. Once approved, it is hardly likely that the Board will suggest to the Department of Justice that it proceed against the conference to collect the fine for failure to file. Even if the Board disapproves, any recommendation to the Department of Justice will probably not result in action.

Disapproval will usually cause the discontinuance of the particular practice. Since the purpose of the government suit is to force filing or discontinuance of the activity, that purpose would have already been achieved by the disapproval.

Moreover, the conference assumes a minimal risk of injury should the agreement be disapproved. The Board may order that the conference cease and desist from the discrimination, and to that extent the conference may be injured. ${ }^{77}$ But there is little precedent for the Board to apply any of the fines in the Ship-

penalties. In point of fact, a suit to collect the section 15 per day fine appears never to have been brought by the government. Other sections of the Shipping Act provide for penalties up to $\$ 25,000$ for each violation. These may be assessed against the offending carrier. It would seem that the $\$ 50,000$ antitrust penalty, imposed on directors individually and not deductible as a business expense, would prove a greater deterrent.

77 "The equity suit is simply an injunction to go ahead and sin no more, and that works pretty well much as it did work in the Methodist community in which I grew up; a man became good for a few weeks but after a year he was the same old reprobate as he was at the beginning of that period." Testimony of Walton Hamilton, Hearings, Subcommittee on the Study of Monopoly Power of the House Judicial Committee, on H.R. 7905, 81st Cong. 2d Sess, Part V, p. 57 (1949). 
ping Act. Because the injured independent may not claim treble damages in an original court action, the most the conference has to fear from the litigious independent is a Board award under the reparations provision of the Shipping Act. However, Board policy and interpretation do not favor the claim of the independent. ${ }^{79}$ The nature of the reparations provision is also incommodious to his claim. ${ }^{80}$ Both considerations augur at best a meager award by antitrust standards. Even after the award the independent must further pursue his claim through a jury trial enforcement proceeding in which the Board's award will serve only as prima facie evidence, ${ }^{81}$ rebuttable by new evidence. ${ }^{82}$

It may be that several policy factors relating to the requirements of filing and approval were crucial to the Court in deciding in Cunard and Far East to disassociate non-filing from antitrust. The Shipping Act at its date of enactment required that all presently existing conferences submit to the Board a written copy of the basic conference agreement pursuant to which the conferences operated..$^{83}$ The agreements that were submitted were broadly phrased. They

${ }^{78}$ See note 76 supra. In American Union Transp., Inc. v. River Plate and Brazil Conferences, 5 F.M.B. 216 (1957), the plaintiff strongly urged that in accordance with the examiner's suggestion the Board recommend that the Attorney General pursue the penalty of $\$ 1,000$ per day for failure by the defendant conference to file the challenged agreement. The Board admitted that there was a "want of clarity in prior Board decisions pertaining to ... the requirement of filing of agreements under $\$ 15$." Quoted from the decision of the Court of Appeals, 257 F.2d 607, 611 (App.D.C., 1958). It would therefore not take any action aimed at the collection of the penalty. But sometime in the future it intended to initiate a rulemaking proceeding that would result in "a more definitive guide."

${ }^{79}$ American Union Transp., Inc. v. River Plate and Brazil Conferences, 126 F.Supp. 91 (S.D.N.Y., 1954), aff'd 222 F.2d 369 (C.A.2d, 1955). The plaintiff then took its complaint to the Maritime Board. On review of the Board decision, 257 F.2d 607 (App.D.C., 1958), the Court of Appeals agreed that section 15 had been violated, and that it was the purpose of the conference to punish the independent. Id., at 613 n.6. However, it chose "not [to] pit its view against that of the Board." Id., at 612. To make its decision more palatable the court gave extended attention to the Board's alternative grounds which distinguished between the services of a "broker" and a "freight-forwarder." The Supreme Court denied certiorari five months after handing down Isbrandtsen. 358 U.S. 828 (1958).

${ }^{80}$ See text at notes $97,109-11$ infra.

8139 Stat. 737 (1916), as amended, 46 U.S.C.A. $\$ 829$ (1958).

${ }^{82}$ In Roberto Hernandez, Inc. v. Arnold Bernstein S., M.B.H., 31 F.Supp. 76 (S.D.N.Y., 1940 ), the plaintiff attempted to enforce a Board award of $\$ 25,000$ against a conference for unjust discrimination. The district court retried the issue and found for the conference on the ground that the plaintiff had failed to mitigate damages, and that the basis for assessing proper damages was speculative. The decision was reversed on appeal. The Court of Appeals concluded that the plaintiff really didn't have an opportunity to mitigate damages. $116 \mathrm{~F} .2 \mathrm{~d}$ 849 (C.A.2d, 1941), cert. denied 313 U.S. 582 (1941). See also, Meeker v. Lehigh Valley R. Co., 236 U.S. 412, 430 (1915); Campagnie Generale Transatlantique v. American Tobacco Co., 31 F.2d 663, 665 (C.A.2d, 1929).

At the enforcement trial, the sum awarded by the Board may be reduced in favor of the defendant. But the court may not increase the sum in favor of the plaintiff. Baltimore \& Ohio R. Co. v. Brady, 288 U.S. 448 (1933).

${ }^{83}$ But it was eleven years after the passage of the Act that the Board first promulgated a rule mildly admonishing the conferences to file their agreements. 46 C.F.R. $\$ 222.15$ (Sept. 1, 1927). However, the following year Congress inaugurated its policy of subsidizing American 
outlined the purposes and activities of the conferences. In all these agreements there were provisions whereby the conference declared a purpose to set rates. The Maritime Board early adopted a "cover of authority" policy whereby the basic conference agreement was held to permit subsequent rate changes without further Board approval. ${ }^{84}$

While this policy of the Board was in effect, it would seem that a conference may have in good faith relied on the inaction of the Board with respect to the agency's requirements as to which types of agreements should be filed. ${ }^{85}$ Thus, in an antitrust suit against a conference there was the possibility that the independent was invoking sanctions against a conference agreement perhaps entitled to approval and exemption. To find a per se price fixing violation in such an agreement would not have appeared equitable under the circumstances. Instead, Cunard permitted the conference to justify the agreement before the Board, irrespective of the fact of previous failure to file.

However, two years after Far Easi the "cover of authority" procedure of the Board was expresslyrejected by the Court of Appeals for the District of Columbia in Isbrandtsen Co.v. United States. ${ }^{86}$ An independent challenged the power of the Board to allow a dual-rate system filed by the conference to go into effect prior to a hearing and formal approval by the Board. The court rejected the Board's contention that the basic conference agreement carried with it the "cover of authority" for subsequent changes. That argument, the court declared, would be inconsistent with the section 15 requirement that agreements or modifications "shall be lawful only when and as long as approved" by the Board. In accordance with this opinion, the Board has radically altered its policy. The "cover of authority" policy has been abandoned. The Board now strictly adheres to the requirement that every agreement and modification be filed for approval. ${ }^{87}$ Thus, it would appear unlikely that a conference agreement remains unfiled with the Board because of the negligence of the parties, or in reliance on

flag carriers. The subsidy program was placed in the administrative control of the Board. It is reliably reported that the Board was "so busy with the problem of subsidy allocation that regulation was not very effective." Koontz, Government Control of Business 229 (1941). To the same effect is a statement by a Shipping Board official, Zeis, American Shipping Policy 168 (1938).

${ }^{84}$ Prior to 1954, "approval" by the Board normally consisted only of routine inspection of agreements and supporting information without a hearing, if the agreements were filed at all. See Ex parte 4, Section 15 Inquiry, 1 U.S.S.B. 121, 124 (1927). Where there was a basic conference agreement, there was no effort by the Board to demand that records of the changes be filed for approval. See also, Marx, International Shipping Cartels 210 (1953).

${ }^{85} \mathrm{~F}$ ew dual-rate agreements were apparently on file. The Board did not urge the filing of such agreements until General Order 76,46 C.F.R. \$236 (1958). "The purpose of the proposed rule is to obtain information with respect to the operation of contract/non-contract rate systems. ..." 17 F.R. 7020 (1952).

${ }^{86} 211$ F.2d 51 (App.D.C., 1954), cert. denied 347 U.S. 990 (1954).

${ }^{87}$ E.g., Conference Limitation on Membership Case, [1957] A.M.C. 1599, 1623. 
the inactivity of the Board. Unfiled agreements henceforth strongly suggest that the parties to the agreement fear disapproval by the Board. Particularly would this appear to be so after Federal Maritime Board $v$. Isbrandtsen $\mathrm{Co}^{88}$

It is now generally known which agreements can be approved and which can not. The opinions in Cunard and Far East contained no hint that the Board could not approve predatory agreements. Indeed, the Maritime Board had itself intervened in a suit on behalf of a conference and argued a construction of the Act that justified the approval of agreements that "obliterate" the competition of independents. ${ }^{89}$ But now that a conference can predict with a degree of certainty whether an agreement will be approved, failure to file must indicate that the conference preferred silence to an admission because the purpose of the agreement was unlawful. Moreover, the element of certainty in the approval functions of the Board alter two other considerations for referring to the Board. Judge Hand in the Cunzard case before the Court of Appeals ${ }^{90}$ voiced the fear that should the court issue an injunction under the antitrust laws, the process of the court might be wasteful should the Board subsequently approve the agreement in question. Turned the other way, it is seen that a strong reason for referral to the Board was the hesitancy of a court to declare an agreement unlawful under antitrust principles when the agreement might be lawful under the regulatory act and, if thus lawful, exempt the parties to it from all liability.

But if an agreement is patently predatory, as for example the same dual-rate agreement declared unlawful in Isbrandisen, then the court need not fear wasting its process. Even if the court is not convinced that the Board would disapprove, it may serve a valuable function in allowing a temporary injunction. The Maritime Board can not provide such relief, but can only issue orders after a full hearing. ${ }^{91}$ Further, should the court decide the antitrust charge on its merits and enjoin certain practices, it is questionable whether subsequent Board approval would automatically dissolve the court order. It would appear that on principles of res judicata a defendant successful before the Board would have to amend the court order before he could resume activities pursuant to Board approval. ${ }^{92}$ This may have been an undesirable procedure where the policies of the Board were at variance with those of antitrust. The Board, it was thought, could approve any agreement it considered in the maritime interests of the United States. Under this broad criterion the Board apparently could approve agreements "destroying competition."

88356 U.S. 481 (1958).

${ }^{89}$ Isbrandtsen Co. v. United States, 96 F.Supp. 883, 893-94 (S.D.N.X., 1951), aff'd per curiam sub nom. A/S J. Ludwig Mowinckels Rederi v. Isbrandtsen Co., 342 U.S. 950 (1952).

${ }_{90}^{90} 50$ F.2d 83 (C.A.2d, 1931).

${ }^{91} 39$ Stat. 736 (1916), as amended, 46 U.S.C.A. $\$ 822$ (1952).

${ }^{92}$ See Judicial Application of Antitrust Law to Regulated Industries, 64 Harv. L. Rev. 1154,1166 (1951), and cases there cited.

${ }^{93} 39$ Stat. 733 (1916), as amended, 46 U.S.C.A. \$814 (1958). 
sideration was a means of harmonizing the variant policies of the two acts. But to the extent that henceforth the Board may not approve predatory agreements even if they further other regulatory policies, Isbrandtsen has declared a rule for the Board in harmony with the policies of the antitrust laws. However, if there will thus occur no clash in policies, then the purpose of harmonizing the two statutes through what Cunard described as supersession of the antitrust laws would appear no longer necessary.

Isbrandtsen has declared that courts which have construed Cunard and Far East as saying that the Board could properly approve predatory conference agreements have misread those cases. It may thus be probable that too many inferences have been drawn from those cases. The belief by some courts that these cases along with Terminal establish that a complainant referred to the Board on primary jurisdiction must exhaust his administrative remedies before resuming his antitrust action, may be unfounded. In Cunard, the independent asked that the rate system be enjoined. In Far East the government also asked for an injunction. In neither case was there a request for temporary relief. An order by the Board could adequately have accomplished the purpose. Moreover, since it then appeared that the Board could well approve the agreements, there was at least a suspicion that the plaintiffs were purposely avoiding the Board for fear of a negative result rather than relying on the antitrust laws to vindicate a right not assertable otherwise.

The question of exhaustion arises in its most pressing form when the plaintiff seeks treble damages. Terminal Warehouse Co. v. Pennsylvania $R$. Co ${ }^{94}$ in its discussion of the Shipping Act, and Keogh v. Chicago \& N.W. Ry. $\mathrm{Co}^{95}$ are the cases generally relied upon for the proposition that upon primary jurisdiction being applied the plaintiff must attempt to seek damages under the reparations provision of the regulatory act. ${ }^{96}$ From these cases the further addition to the doctrine is made that damages by way of reparations are an adequate substitute for the antitrust treble damages. However, it would appear crucial that in Terminal and Keogh the plaintiff seeking treble damages was not an independent competitor but a shipper. In both cases the plaintiff had first sought relief before the ICC. After being refused damages by the Commission, the shipper brought a treble damage action against the carriers. The violation alleged was a conspiracy to charge higher rates to the injury of the shipper. The Circuit Court in Terminal held that the shipper was barred from the antitrust damage remedy if the Commission had rejected his claim. The Supreme Court went on to say that the Commerce Act had made unavailable the antitrust remedy.

It would appear that the statement by the Court in Terminal was peculiarly

94297 U.S. 500 (1936).

${ }^{95} 260$ U.S. 156 (1922).

${ }^{98}$ See cases cited in note 20 supra. 
fitting for the facts of the case. First, it appeared that the shipper was trying to get by indirection through antitrust what he could not get by way of the Commission. ${ }^{97}$ The complaint technically charged a violation of the antitrust laws. But the identical issue of discriminatory rates had already been adjudicated in an adversary proceeding before the Commission. Second, even had there been no prior proceedings before the Commission, the agency and not the court appeared to be the more appropriate forum, because: (1) The Commission idea was originally conceived as a convenient and inexpensive forum for shippers who could proceed against the carriers without the funds necessary to maintain an elaborate trial; (2) The Commission was authorized to award reparations. This form of money award was regarded as adequate relief for rates charged above the legal tariff. It is in fact a remedy for breach of contract or quasi-contractual obligation to charge reasonable rates;98 (3) Courts prefer to leave questions of rate overcharges to the agencies because of the general policy of the regulatory acts for uniform treatment of shippers. If the court should award treble damages to one shipper, that alert suitor would gain an advantage over competing shippers who were not parties to the suit; ${ }^{99}$ (4) To adjudicate an alleged overcharge would involve the court in considerations as to what a reasonable rate should have been. Railroad rate determination had been designated by Congress as an exclusive administrative function.

Thus, it may accurately be said that Terminal only established the requirement of exhaustion of remedies when primary jurisdiction applied to shippers. Indeed, there appears to be good reason for a distinction in this rule between shippers and independent competitors.

The independent appears to have particular reason for seeking the antitrust remedy rather than proceeding under the Shipping Act. The independent may feel that both the Board's cease and desist order and its power to grant reparations are not adequate substitutes for the antitrust remedies. The Board cannot issue injunctions as such. ${ }^{100}$ It has disclaimed power to enjoin threatened

${ }^{97}$ In American Union Coal Co. v. Pennsylvania R. Co., 159 Fed. 278 (E.D.Pa., 1908), the court held that a complaint for alleged overcharges charged a violation of the Interstate Commerce Act and not the Sherman Act. It would not permit a shipper to dress up an alleged violation of the Commerce Act in antitrust language in an effort to collect treble damages. The antitrust portion of the complaint was accordingly dismissed.

${ }^{98}$ Northwestern Oil Co. v. Socony Vacuum Oil Co., 138 F.2d 967, 970 (C.A.7th, 1943); Hawaiian Airlines v. Trans-Pacific Airlines, 78 F.Supp. 1, 4-5 (D.Hawaii, 1948).

${ }^{99}$ Keogh v. Chicago \& N.W. Ry. Co., 260 U.S. 156, 163 (1922). But the criterion of uniformity has no application in an antitrust suit by an independent competitor. Story Parchment v. Paterson Parchment Paper Co., 282 U.S. 555 (1931).

Parity among shippers also involves industry-wide considerations. Exaction of the legal rate which is alleged to be excessive involves considerations as to the ability of the shipper relative to his competitors to pass on the rate differential to his customers.

100 United States v. Far East Conference, 94 F.Supp. 900 (D.N.J., 1951), rev'd on other grounds 342 U.S. 570 (1952); New York \& Porto Rico S.S. Co. v. United States, 32 F.Supp. 538 (S.D.N.Y., 1940), rev'd on rehearing on other grounds 36 F.Supp. 190 (E.D.N.Y., 1940). Note the statutory provision in 39 Stat. 737 (1916), as amended, 46 U.S.C.A. $\$ 828$ (1958). 
violations of the Act. ${ }^{101}$ It will provide relief only for actual violations..$^{102}$ Orders of the Board must be enforced by a district court having jurisdiction over the defendant carriers. Further, the Board can neither grant temporary relief, nor modify its own previous orders prior to a full hearing. ${ }^{103}$ Between the filing of a complaint and the time for hearing several years may elapse. ${ }^{104}$ Thus, if an independent is not to be driven out of the trade by a conspiracy against him, he must seek the aid of the district court in the first instance to obtain temporary injunctive relief ${ }^{105}$ by showing irreparable injury. ${ }^{106}$ Here he must produce much of the same evidence he would ordinarily present in a regular antitrust suit. ${ }^{107}$ The temporary injunction may of course be appealed by the conference, so that the independent may have to litigate through the courts while his petition is pending before the Board.

If the independent must proceed before the Board and present all his evidence of a conspiracy against him, he does not have the advantages of the liberal discovery procedures that he may employ under the antitrust laws. ${ }^{108}$ Since he must prove before the Board much the same charges as he would have to in the antitrust suit, lack of discovery procedure may constitute a serious disadvantage. ${ }^{109} \mathrm{He}$ also loses the jury trial to which he otherwise would be entitled.

${ }^{102}$ Chicago, Benton Harbor \& South Haven Transit Co. v. Goodrich Transit Co., Complaint Docket 40, June 23, 1927, discussed in Wisconsin \& Michigan Transp. Co. v. Pere Marquette L.S., 67 F.2d 937 (C.A.7th, 1933). Note also the provisions of 39 Stat. 736 (1916), as amended, 46 U.S.C.A. \$821 (1958).

10239 Stat. 736 (1916), as amended, 46 U.S.C.A. $\$ 821$ (1958). See note 49 supra.

${ }^{103}$ See United States Trucking Corp. v. American Export Lines, 146 F.Supp. 924 (S.D.N.Y., 1956).

${ }^{104}$ See Rivoli Trucking Corp. v. New York Shipping Ass'n, 167 F.Supp. 943 , 945 (S.D.N.Y., 1957); Riss \& Co. v. Association of American Railroads, 170 F.Supp. 354, 368-69 (D.D.C., 1959).

${ }^{105}$ In West India Fruit \& S.S. Co. v. Seatrain Lines, Inc., 170 F.2d 775 (C.A.2d, 1948), the court sustained an injunction granted with the Board's approval on the theory that the Board lacked power to grant relief pending its determination on a formal complaint. See Isbrandtsen Co. v. United States, 81 F.Supp. 544, 547 (S.D.N.Y., 1948), aff'd per curiam sub nom. A/S J. Ludwig Mowinckels Rederi v. Isbrandtsen Co., 336 U.S. 941 (1949); Jewett Bros. \& Jewett v. Chicago, M. \& St. P. Ry. Co., 156 Fed. 160, 167 (C.C.S.D., 1907).

${ }^{108}$ See United States v. Borax Consolidated, Itd., 141 F.Supp. 396 (N.D.Cal., 1955). "The size and scope of the conspiracy alleged would make necessary a lengthy and costly hearing [on the prayer for interim relief]. Preparation for this would involve the same kind of detailed discovery that is now going on in preparation for the trial itself." Riss \& Co. v. Association of American Railroads, 170 F.Supp. 354, 368 (D.D.C., 1959).

${ }^{107}$ Although the Board is empowered to implement the regulatory provisions of the Shipping Act, it may look to evidence concerning any aspect of the shipping industry in judging a complaint. It is not restricted to evidence of specific practices among particular conference members. Atlantic \& Gulf/West Coast Conference v. United States, 94 F.Supp. 138 (S.D N.Y., 1950). 1959).

${ }^{108}$ See Riss \& Co. v. Association of American Railroads, 170 F.Supp. 354, 369 (D.D.C.,

${ }^{109}$ A plaintiff in an antitrust treble damage action may demand a jury trial. Fleitman v. Welsbach Street Lighting Co., 240 U.S. 27 (1916); Blechman v. Kleinert Rubber Co., 98 
Moreover, the treble damages contemplated by the antitrust laws are not usually for charges over the legal tariff. The independent is not claiming breach of contract damages, but rather damages which are partly tort and partly penal. ${ }^{110}$ The independent frequently asserts that it has sustained injuries which are measurable in terms of damage to the good will, to business, the property, the competitive position and the future prospects of the independent carrier in the trade. ${ }^{111}$ Such damages the Board cannot award. ${ }^{112}$ Indeed, there may be no damages awarded as reparations to an independent where under antitrust very sizeable damages would be awarded. Further, even where reparations may be available in part, the independent must contend with two short statutes of limitations. He has two years within which to file a complaint before the Board. If he is successful in his claim, he must enforce the money award within one year by re-trying the Board award in a court of law before a jury. Thus, where primary jurisdiction is applied and the court dismisses, the limitations provision of the Shipping Act may well have run. If the independent loses in his reparations claim before the Board, he is foreclosed from initiating an antitrust charge on the same or related facts. ${ }^{113}$ If he succeeds before the Board it would appear that he is barred from antitrust damages under an election theory. ${ }^{114}$

F.Supp. 1005 (S.D.N.Y., 1951). Section 22 of the Shipping Act only provides for a jury trial in the enforcement proceedings at the defendant's choice.

In theory, the plaintiff may be said to retain the privilege of an antitrust jury trial after the Board proceedings. But since there is also the requirement of exhaustion once the plaintiff is before the Board, in practical effect the administrative proceedings are dispositive of the claim. Cases such as S.S.W., Inc. v. Air Transport Ass'n of America, 191 F.2d 658 (App.D.C., 1951), cert. denied 343 U.S. 955 (1953), which outline a two-step procedure, are confined to agencies powerless to award reparations, such as the CAB and the FPC.

${ }^{110}$ Northwestern Oil Co. v. Socony-Vacuum Oil Co., 138 F.2d 967, 970 (C.A.7th, 1943); Story Parchment v. Paterson Parchment Paper Co., 282 U.S. 555 (1931). See note 97 supra.

111 Cf. Story Parchment v. Paterson Parchment Paper Co., 282 U.S. 555 (1931).

112 See Slick Airway, Inc. v. American Airlines, 107 F.Supp. 199 (D.N.J., 1952), aff'd on rehearing, 107 F.Supp. 214, 216, 218, appeal dismissed sub nom. American Airlines v. Forman, 204 F.2d 230 (C.A.3d, 1953), cert. denied 346 U.S. 806 (1953) (reparations provision of the Civil Aeronautics Act); Hawaiian Airlines v. Trans-Pacific Airlines, 78 F.Supp. 1, 4-5, 8 (D.Hawaii, 1948) (reparations provision of Shipping Act); Meeker v. Lehigh Valley R. Co., 183 Fed. 548, 551 (C.A.2d, 1910) (reparations provisions of Commerce Act); Jewett Bros. \& Jewett v. Chicago, M. \& St. P. Ry. Co., 156 Fed. 160, 167 (C.C.S.D., 1907) (same); McClellan v. Montana-Dakota Utilities, 95 F.Supp. 977 (D.Minn., 1951). These cases are a minority. But the reparations provision of the Shipping Act has been strictly construed. Prince Line v. American Paper Exports, 55 F.2d 1053 (C.A.2d, 1932).

${ }_{113}$ Pennsylvania R. Co. v. Terminal Warehouse Co., 78 F.2d 591 (C.A.3d, 1935), aff'd 297 U.S. 500 (1936).

${ }^{114}$ If the complaint of the independent is limited to the charge that a conference is operating under an unapproved agreement, or an agreement broader than one actually approved, judicial review of an adverse decision by the Board may not lie. In Associated-Banning Co. v. United States, 247 F.2d 557 (App.D.C., 1957), the question of standing to appeal a Board decision on such a question was raised. The court decided the case on other grounds but in dictum indicated its answer to this question: "That $\$ 15$ authorizes the Board to act in the public interest is clear; not so, that its action, once taken, is subject to review at the instance of those asserting private rights." Id., at 561 n.9. Cf. Perkins v. Lukens Steel Co., 310 U.S. 113, 125 (1940). 
It may be suggested that after proceeding before the Board the independent should be allowed to waive any claim to reparations and resume or begin a treble damage action. Or, in the alternative, that after any reparation award, the independent should collect the additional difference between treble damages and reparations. In the first situation, were it possible, the independent would risk losing any reparations he may be entitled to for the sake of antitrust. If unsuccessful in the antitrust action he would most likely be unable to return to the reparations remedy because of the short limitations. In both cases the conference might delay the proceedings before the Board and before the court of enforcement until the antitrust statute of limitation on the injury had run. Even the threat of such delay is a potent weapon. ${ }^{115}$

The distinction between an antitrust claim made by an independent and one made by a shipper was read into the Shipping Act by the Court in Isbrandtsen. The Shipping Act, the Court noted, applies a different standard to practices designed to injure a competitor. A conference may not "resort to any other discriminatory or unfair methods" against an independent, but the conference may enter into agreements which the Board may properly approve as long as they are not "unjustly discriminatory" or "unjustly prejudicial" with respect to shippers. The addition of the modifier "unjustly" was explained by Isbrandtsen as a direction to the Board that it may approve some discrimination against shippers but no discrimination by a conference against an independent. ${ }^{116}$

Recent lower court railroad cases offer another basis for distinguishing an antitrust action by an independent. In Atchison, Topeka \& Santa Fe R. Co. v. Aircoach Transport Ass' $n,{ }^{117}$ decided by the Court of Appeals for the District of Columbia the same week Isbrandtsen was handed down, it was held that the district court need not refer to the ICC the issue whether a rate quotation was made as part of a combination or conspiracy to eliminate a competitor. The court suggested that it would be possible for the district court to hold a special hearing to determine the predatory nature of the rate agreement. Subsequently, the same court in Atlantic Coast Line R. Co. v. Riss \& Co.118 interpreted Isbrandtsen as requiring that the issue of the intent and effect of an agreement must be referred to the regulatory agency "where such issue is the sole or dominant

115 "Primary jurisdiction may be part of a deliberate delay to exhaust plaintiff's finances." Testimony of Walton Hamilton, Hearings, Subcommittee on the Study of Monopoly Power of the House Judicial Committee, on H.R. 7905, 81st Cong., 1st Sess.Part I, p. 290-91 (1949).

Compare the added burden to the private litigant contending with primary jurisdiction with the policy of section 5 of the Clayton Act. Note 76 supra. ". . . Congress itself has placed the private antitrust litigant in a most favorable position through the enactment of $\$ 5$ of the Clayton Act. . . . In the face of such a policy this Court should not add requirements to burden the privatelitigant beyond what is specifically set forth by Congress in those laws." Radovich v. National Football League, 352 U.S. 445, 454 (1957).

${ }_{116}$ Federal Maritime Board v. Isbrandtsen Co., 356 U.S. 481, 495 (1958).

${ }^{117} 253$ F.2d 877 (App.D.C., 1958).

${ }^{118}$ CCH Trade Reg. Rep. $\llbracket 69,122$ (App.D.C., 1958) (petition for cert. granted and case remanded). 
issue in the case." But, "where the agreement is only one of a considerable number of overt acts alleged and where the policy favoring referral is clearly outweighed by other factors such as the probability of undue delay and the overriding importance of early consideration of the overt acts alleged," referral to the Board need not be made.119 This rule, it seems, would ordinarily apply in favor of the independent in an antitrust suit. Likewise, the rule ordinarily would seem not to apply to antitrust actions by shippers. The shipper charging disciminatory rates will put into evidence the rate charged and what he believes should have been the appropriate non-discriminatory rate. The independent on the other hand will generally allege many examples of the conduct of conference members. All the allegations taken together are designed to show, largely through a cumulative presentation of circumstantial evidence, that there does in fact exist such a conspiracy and that the plaintiff has been or will be injured by it. It will be an unusual predatory agreement that consists exclusively of a rate practice. The Court of Appeals formulated this rule without mention of Cunard. In that case the independent entered a variety of allegations against the conference which he declared were examples of the conspiracy. ${ }^{120}$ But the court insisted on treating the complaint as if it had alleged no more than an unlawful rate system.

Thus, it would appear that a court has its choice of several theories to avoid the results of Cunard, Terminal and Far East. It may refuse to refer any unfiled agreement by following the precedents set out in Borden and Alkali.121 It may decide that Isbrandtsen Co.v. United States altered the need for the Cunard procedure in that non-filing can no longer be justified by the reliance of the conference on Board inactivity with respect to the "cover of authority" policy of the Board. The court may reason from Federal Maritime Board $v$. Isbrandtsen Co. ${ }^{122}$ to a presumption of the predatory nature of the agreement from the fact of its not being filed. Or, the court may adopt Judge Forman's view, which apparently has been revived recently in Aircoach, that the exemption provision of the regulatory statutes applies only to the technical rate-setting practices in the industry. Two further theories are still left. The court may adopt the distinction between independent and shipper. If there are many allegations the result reached in Riss may be employed. If the allegations are few and call for Board consideration, then reasoning from Isbrandtsen the court may stay the antitrust proceedings to determine the single question of the predatory nature of the agreement. This procedure could be employed without dismissal and in a manner analogous to a court utilizing the superior fact-finding capacity of a master. No exhaustion of remedies need follow such limited referral.

${ }^{119}$ Ibid. Accord: Noerr Motor Freight, Inc. v. Eastern Railroad Presidents Conference, 155 F.Supp. 768 (E.D.Pa., 1957); Parmelee Transp. Co. v. Keeshin, 144 F.Supp. 480 (N.D.Ill., 1956).

${ }^{120}$ See note 9 supra.

121 See note 67 supra.

122356 U.S. 481 (1958). 
III

To the three questions posed by the R.C.A. case as important considerations in applying primary jurisdiction, several tentative answers may now be proposed. It does not appear to have been the intent of Congress to supersede the antitrust laws by the Shipping Act and thereby render antitrust inapplicable to shipping. On the contrary, the antitrust laws can serve to loose the power of the conference to limit independent competition. Competition with the conferences by tramps and independents operating as part liners and part tramps appears as intended by Congress to insure that the conferences would be unable to charge differing rates for similar service to various classes of shippers under the guise of uniform rates.

Although the shipping industry is heavily regulated, there is room for arguing the applicability of antitrust when the combination sought to be regulated in return for exemption from antitrust does not submit to the form of regulation. Although Cunard and Far East early took a position that failure to file is irrelevant, the rule of those cases has slowly been whittled away by doctrines tightly encompassing those cases. In areas of regulated transportation other than shipping, rationales have been suggested to avoid the results of Cunard and Far East. Although shipping cases have most closely followed the rule of Cunard, Federal Maritime Board v. Isbrandtsen Co. was a severe set-back for the conferences. That case appears to foreshadow less deference to the Board in the future.

It is with respect to the issue of rates that primary jurisdiction in the shipping industry appears to remain a requisite. Where rates are concerned the jurisdiction of the Board is difficult to deny. In this area the agencies have been regarded as particularly competent since the first transportation commission was established. Thus, the resolution of Cunard still applies as to strict questions of rates. But in the context of the antitrust suit the Board's jurisdiction over rates has not escaped attack. The strongest assault has been by way of re-interpreting the nature of the Board's power to exempt. Advocates of this view would reduce the regulatory exemption provision so that only technical rate-setting agreements are covered by the exemption. Should the Supreme Court eventually adopt this argument, the Maritime Board in particular would be stripped of power since, unlike other commissions, it has no authority to set rates.

A more indirect attack on the Board's jurisdiction over rates lies in the distinction between independent and shipper and the related distinction between the sole or dominant rate allegation and the rate allegation as one of many charges. The inherent danger in this approach is that the court may make too much turn on the allegations. Such a doctrine would appear to tempt plaintiffs to pad their complaints so as to avoid referral to the Board. Where this occurs, the court may adjudicate the merits only to find that referral to the Board 
should have been made initially. ${ }^{123}$ However, there appears to be a question of possible costly and protracted delay whichever way the court decides. If it refers to the Board, the independent may be injured by the delay. If it doesn't, the conference may be harmed. But in a balance of interests it would seem as if greater consideration is due the independent. Since the plaintiff will be in court only where there is an unfiled agreement, at any time before or during the antitrust proceedings, the conference is free to file with the Board. If on the other hand the conference denies the existence of a predatory agreement, then the plaintiff who is presumably ready, willing and able to prove such an agreement before the court should not be forced to prove it before the agency, as the principal reason for referral would be to secure a possible exemption for the agreement. As a practical matter the court, it would seem, may safely assume that the conference knows the requirements of the Board. ${ }^{124}$ Having assumed the risks of non-filing, the conference should not be thus able to retrace their steps and seek approval only when the antitrust suit is upon them. ${ }^{125}$ Retroactive immunity in this form results in the anomaly that violation of the Shipping Act provides at least temporary immunity from the antitrust laws.

With respect to an admitted agreement involving rates, Isbrandtsen in dictum admits the necessity of preliminary Board consideration. But this referral, it is noted, is minimal. It is to be made for findings of fact as to the nature of the agreement. However, Isbrandtsen did not face the situation where the answer of the Board would be obvious to the court. It may be that courts in the future will be inclined to dispense with primary jurisdiction in such situations even as to question of rate practices. ${ }^{126}$

The respective roles of antitrust and maritime regulation ultimately rest on broad considerations of policy. Primary jurisdiction as a doctrine suitable for adjusting the shifting economic preferences of courts and Congress is at present

123 "But it is urged . . . that the assertion by the district court of its jurisdiction, without awaiting an investigation by the Commission, will entail protracted litigation and impose on the parties great expense before the error can be corrected on appeal from the final judgment of this Court." United States Alkali Ass'n v. United States, 325 U.S. 196, 201 (1945). See also, Note, 66 Harv. L. Rev. 1124-25 (1953).

${ }^{124}$ In Hazard's Adm'r v. New England Marine Ins. Co., 8 Pet. (U.S.) 557, 581-82 (1834), the Court held that maritime underwriters are presumed to know the usages of the trade.

125 United States v. El Paso Natural Gas Co., CCH Trade Reg. Rep. I68,872 (D.Utah, 1957), cert. denied 355 U.S. 950 (1958).

128 The findings of fact in a determination as to the predatory nature of an agreement presumably include actual elimination of competitors, and the manner of such elimination. Courts may ultimately rely on the holding of American Tobacco Co. v. United States, 328 U.S. 781 (1946), to dispense with even this limited referral. The Court there held that actual exclusion of competitors is not necessary for a showing of antitrust violation. "It is not the form of the combination or the particular means used but the result to be achieved that the statute condemns." Id., at 809. Part reliance was placed on this aspect of American Tobacco in Slick Airway, Inc. v. American Airlines, 107 F.Supp. 199 (D.N.J., 1952), and Riss \& Co. v. Association of American Railroads, 170 F.Supp. 354, 363-64 (D.D.C., 1959). 
in a state of flux. With the post-war energetic enforcement of antitrust by the Department of Justice, the Supreme Court in cases such as Isbrandtsen and R.C.A. has appeared to shy away from the agencies in matters relating to antitrust. A related tendency is the resolution of formerly divergent regulatory and antitrust policies in favor of the policy of greater competition via the road of judicial review. ${ }^{127}$ Also, a growing antipathy by the Supreme Court to exclusive arrangements has been evident. ${ }^{128}$ One must admit the present primacy of antitrust over regulation. But to the extent that the Court is willing to overturn former precedents, primary jurisdiction in antitrust suits will be a rapidly changing doctrine. This may be especially true in the shipping industry where regulation by the Maritime Board has had its strongest hold.

${ }^{127}$ E.g., United States v. R.C.A., 358 U.S. 334 (1959).

${ }^{128}$ E.g., Northern Pacific Ry. Co. v. United States, 256 U.S. 1 (1958); Denver Union Stock Yard Co. v. Producers Livestock Marketing Ass'n, 356 U.S. 282 (1958); Standard Oil Co. of California v. United States, 337 U.S. 293 (1949).

\section{AN ATTORNEY GENERAL'S STANDING BEFORE THE SUPREME COURT TO ATTACK THE CONSTITUTIONALITY OF LEGISLATION}

The Supreme Court has often invoked the rule that a public official has no standing to attack the constitutionality of legislation which he is charged with enforcing. ${ }^{1}$ While this general rule appears well established, it is not clear whether an attorney general, as contrasted with other public officials, is in all cases within the scope of the rule. This issue was raised, but not reached, during the Court's 1958 term in Alaska v. American Can Co., in which the Alaska Attorney;General attacked the constitutionality of an Alaska statute as construed by the lower courts. ${ }^{3}$ The purpose of this comment is to examine this question and see in what situations, if any, an attorney general, state or federal, should have standing before the Supreme Court to challenge the constitutionality of legislation of his own jurisdiction. ${ }^{4}$

${ }^{1}$ Stewart v. Kansas City, 239 U.S. 14 (1915); Braxton County Court v. West Virginia, 208 U.S. 192 (1908); Smith v. Indiana, 191 U.S. 138 (1903); Caffery v. Oklahoma Territory, 177 U.S. 346 (1900). See also, the separate opinion of Justice Frankfurter in Coleman v. Miller, 307 U.S. 433, 460 (1939); The Power of a State Officer to Raise a Constitutional Question, 33 Col. L. Rev. 1036 (1933).

\section{U.S. 224 (1959).}

${ }^{3}$ Brief for Petitioner at 11.

"The scope of this comment is limited to those cases where an attorney general attacks acts of his own legislature. It is a quite different question, and well settled, that an attorney general, in the name of his government, may question the constitutionality of legislation of another government. See United States v. Standard Oil Co. of California, 21 F.Supp. 645 (S.D.Cal., 1937) (federal versus state legislation); Ohio v. West Virginia, 262 U.S. 553 (1923) (state versus another state's legislation); Hopkins Savings Ass'n v. Cleary, 296 U.S. 315 (1935) (state versus federal legislation); cf. Massachusetts v. Mellon, 262 U.S. 447 (1923). 